\title{
BIOCHEMICAL ECOLOGY OF EXTREMELY THERMOPHILIC BACTERIA 1979 FIELD STUDY IN YELLOWSTONE NATIONAL PARK
}

\author{
Robert F. Ramaley \\ Department of Biochemistry \\ University of Nebraska Medical Center \\ Omaha, Nebraska 68105 \\ and
}

Lily A. Jones

Department of Immunology and Microbiology

Wayne State University School of Medicine

Detroit, Michigan 48200

\section{Objectives}

The primary objective of the brief (one week) 1979 summer field studies conducted in Yellowstone National Park was to collect samples of the pink filamentous bacterial masses growing at $80-90^{\circ} \mathrm{C}$ in two Yellowstone hot spring runoff channels (Octopus Spring and Artist's Paintpots) for subsequent biochemical analysis. In addition, samples were also taken from the runoff channels for bacterial culture and isolation of extremely thermophilic bacteria (including actinomycetes) and some additional Yellowstone thermal areas were also surveyed for the presence of the pink filamentous bacterial masses.

\section{Procedures}

The samples for subsequent culture of bacteria were collected in sterile 10 or $50 \mathrm{ml}$ plastic centrifuge tubes or sterile Whirl-Pak bags, transported to the University of Wyoming National Park Service Center (US-NPS), and stored at refrigerator temperatures.

Because of the short time available for the 1979 field studies and the limited equipment that could be brought from Omaha, the only samples cultured at the UW-NPS center were those for the extremely thermophilic actinomycetes $\left(65^{\circ} \mathrm{C}\right)$. These samples included those from various points in the runoff channel of 0ctopus Spring. A few additional soil samples from other Yellowstone thermal areas were also taken for later culture at Wayne State University (media indicated in Appendix). The medium for the quantitation of Thermus type isolates was the $0.1 \%$ $\mathrm{w} / \mathrm{v}$ yeast extract, $0.1 \% \mathrm{w} / \mathrm{v}$ tryptone, Castenholz salt medium, pH 8.0 previously reported (Ramaley and Hixson, 1970) and the medium for thermophilic Bacillus isolates was standard Nutrient Agar (pH 6.8).

The samples for biochemical characterization were collected by placement 
of sterilized (autoclaved) cotton strings (loops) across the runoff channel of Octopus Spring and one small spring in the Artist's Paintpot area (the spring to the right as one faces the bluff). The strings were anchored with concrete nails. After one week the strings from the Octopus Spring (with attached bacteria) were removed and taken to the UW-NPS center, transported to Omaha on ice, and stored at $-20^{\circ} \mathrm{C}$. The bacteria accumulating after one week in the Paintpot area were stripped off the strings, placed in sterile bags, transported to Omaha, and stored at $-20^{\circ} \mathrm{C}$. The Paintpot strings were left in for an additional month, at which time all but one set were removed by Fred Hirschmann (NPS), and sent to Omaha. One string set was left in the runoff channel by Mr. Hirschmann to see what extent of bacterial mass will be accumulated on this string set by next summer. (similar over-winter string sets had been previously obtained from the Octopus spring runoff channel (1978 Field Studies Report to UW-NPS Center).

\section{Results}

Biochemical analysis of the bacterial masses has been set aside temporarily because of the observation that the bacterial mass consists of two different bacteria. However, we have made one very interesting observation. While the pink pigmentation of the masses from Octopus Spring appear to be carontenoid (extraction by acetone; Bauman and Simmonds, 1969) the pigmentation of the masses from Artist's Paintpot bacterial masses are not acetone soluble and the masses from Artist's Paintpot also seem to be morphologically different from those of the runoff channel of Octopus Spring.

Culture of these pink filamentous bacteria under standard laboratory conditions has still not been possible as of this time using a wide variety of media and conditions including anaerobic conditions. Since these bacterial masses consist of two different bacterial types (as determined by thin section electron microscopic observation) and since neither of them seem to be culturable as a heterotrophic bacterium it is probable that they derive some mutually advantageous benefit from their growth together in the upper end of the hot springrunoff channel. Present studies are currently underway to determine the possible source of energy for growth of these bacteria. Ramaley and Cook (1979) showed that one of the bacteria has some type of intracellular vesicular structure that resembles, but is not identical to that found in photosynthetic bacteria.

Examination of the samples cultured at UW-UPS Center and at Wayne State by $L$. Jones have shown that thermophilic actinomycetes are not readily isolated and do not appear to particigate as major contributors to the microbial ecology of the upper end $\left(60^{\circ}-90^{\circ} \mathrm{C}\right)$ of hot spring runoff channels has also been reported (M. Tansey, Indiana U., personal communication). 


\section{Conclusions}

From preliminary studies of the pink bacterial masses from the upper end of the runoff channels (temperature $80-92^{\circ} \mathrm{C}$ ) of 0ctopus Spring and one of the springs of the Artist's Paintpot area, it appears that the two populations may be more different than originally thought. For example, the pink pigmentation of the Octopus Spring masses is easily removed by acetone extraction suggesting as postulated by Bauman and Simmonds (1969) that they are carotenoids. However, the pigmentation of the masses from Artist's Paintpots is not extractable by acetone or othef organic solvents. There also appears to be some morphological differences between the two masses and scanning electron microscopic studies are planned for the future.

From the bacterial culture studies conducted by L. Jones at UW-NPS Center and followed up at Wayne State University, it appears that thermophilic actinomycetes do not play any numerically important role in the microbial ecology in the upper ends of the runoff channels at Octopus Spring. Enrichment and direct plating of these samples yielded only Thermus aquaticus (Brock and Freeze, 1969) type bacterial isolates and Bacillus sterothermophilus isolates. Further attempts to obtain the bactería in laboratory culture from pink bacterial are conventional hetertrophic bacteria capable of growth in conventional or low organic bacterialogical media.

\section{Acknowledgements}

We want to thank Dr. Kenneth Diem, Director of UW-NPS for his hospitality and advice that allowed us to make possible the above field studies of the extremely thermophilic bacteria in Yellowstone National Park.

\section{Literature Cited}

Bauman, A.J. and P.G. Simmonds. 1969. Fatty acids and polar lipids of extremely thermophilic filamentous vacterial masses from two Yellowstone hot springs. J. Bacteriol. 98: 528-531.

Brock, T.D. and H. Freeze. 1969. Thermus aquaticus gen. n. and sp. n., a nonsporulating extreme thermophile. J. Bacteriol. 98: 289-297.

Brock, T.D. 1978. Thermophilic microorganisms and life at high temperatures. Springer-Verlag, New York, Heidelberg and Berlin.

Ramaley, R.F. and J. Hixson. 1970. Isolation of a nonpigmented, thermophilic bacterium similar to Thermus aquaticus. J. Bacteriol. 103: 527-528.

Ramaley, R.F. and W. Cook. 1979. Thermostability and comparative properties of enzymes isolated from natural hot spring populations. $X I$. International Congress of Biochemistry. 
Appendix I. MEDIA USED IN ATTEMPTS TO ISOLATE THERMOPHILIC ACTINOMYCETES

1. Czapek's agar $(\mathrm{Cz})$

\begin{tabular}{|c|c|c|}
\hline $\mathrm{NaNO}_{3}$ & $2 \mathrm{gm}$ & \\
\hline $\mathrm{K}_{2} \mathrm{HPO}_{4}$ & $1 \mathrm{gm}$ & \\
\hline $\mathrm{MgSO}_{4}-7 \mathrm{H}_{2} \mathrm{O}$ & $0.5 \mathrm{gm}$ & \\
\hline $\mathrm{KC1}$ & $0.5 \mathrm{gm}$ & \\
\hline $\mathrm{FeSO}_{4}$ & $0.01 \mathrm{gm}$ & \\
\hline Sucrose & $30 \mathrm{gm}$ & \\
\hline Agar & $15 \mathrm{gm}$ & \\
\hline $\mathrm{H}_{2} \mathrm{O}$ & 1 1iter & $(\mathrm{pH} 6.6)$ \\
\hline
\end{tabular}

2. Glucose-asparagine agar (Glu-Asm)

\begin{tabular}{|c|c|c|}
\hline Glucose & $10 \mathrm{gm}$ & \\
\hline Asparagine & $0.5 \mathrm{gm}$ & \\
\hline $\mathrm{K}_{2} \mathrm{HPO}_{4}$ & $0.5 \mathrm{gm}$ & \\
\hline Agar & $15 \mathrm{gm}$ & \\
\hline $\mathrm{H}_{2} \mathrm{O}$ & 1 liter & $(\mathrm{pH} 6.8)$ \\
\hline
\end{tabular}

3. Glycero1-asparagine agar (G1y-Asm)
G1ycerol
$10 \mathrm{gm}$
Asparagine
$1 \mathrm{gm}$
$\mathrm{K}_{2} \mathrm{HPO}_{4}$
$1 \mathrm{gm}$
Agar
$15 \mathrm{gm}$
$\mathrm{H}_{2} \mathrm{O}$
1 liter
$(\mathrm{pH}$ adjusted to 7.0$)$

4. Peptone-yeast extract (PY)

$\begin{array}{ll}\text { Peptone } & 5 \mathrm{gm} \\ \text { Yeast extract } & 3 \mathrm{gm} \\ \mathrm{Ca}\left(\mathrm{NO}_{3}\right)_{2} & 0.5 \mathrm{gm} \\ \mathrm{Agar} & 15 \mathrm{gm} \\ \mathrm{H}_{2} \mathrm{O} & 1 \text { liter }\end{array}$

5. Tryptone-yeast extract, glucose (TYG)

$\begin{array}{ll}\text { Tryptone } & 5 \mathrm{gm} \\ \text { Yeast extract } & 3 \mathrm{gm} \\ \text { Glucose } & 10 \mathrm{gm} \\ \mathrm{K}_{2} \mathrm{HPO}_{4} & 1 \mathrm{gm} \\ \mathrm{KH}_{2} \mathrm{PO} & 0.1 \mathrm{gm} \\ \mathrm{Agar} & 15 \mathrm{gm} \\ \mathrm{H}_{2} \mathrm{O} & 1 \text { iiter }\end{array}$

$(\mathrm{pH} \mathrm{7.0)}$ 
Appendix I. Media (continued)

6. Reproductive medium 1. (RM-1)

$\begin{array}{ll}\text { Glucose } & 10 \mathrm{gm} \\ \text { Peptone } & 2 \mathrm{gm} \\ \text { Yeast extract } & 2 \mathrm{gm} \\ \text { Casomino acids } & 2 \mathrm{gm} \\ \mathrm{MgSO}_{4} & 0.5 \mathrm{gm} \\ \mathrm{Agar} & 20 \mathrm{gm} \\ \mathrm{H}_{2} \mathrm{O} & 1 \text { iter }\end{array}$

7. Actinomycete medium - simple (AMS)

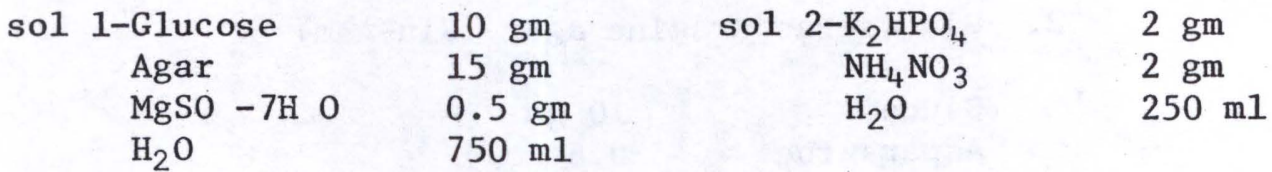

After autoclaving, two solutions are mixed and dispensed ( $\mathrm{pH}$ 6.8-7.

8. Minimal actinomycete medium (MAM)

$\begin{array}{ll}\text { sol } 1-G l u c o s e & 20 \mathrm{gm} \\ \mathrm{MgSO}_{4} & 0.5 \mathrm{gm} \\ \mathrm{NH}_{4} \mathrm{NO}_{3} & 2 \mathrm{gm} \\ \text { Asparagine } & 1 \mathrm{gm} \\ \text { Agar } & 15 \mathrm{gm} \\ \mathrm{H}_{2} \mathrm{O} & 750 \mathrm{ml}\end{array}$
sol 2-Succinic acid $0.5 \mathrm{gm}$ $\mathrm{K}_{2} \mathrm{HPO}_{4} \quad 5.0 \mathrm{gm}$
$\mathrm{H}_{2} \mathrm{O}$ $250 \mathrm{~m} 1$

Each solution adjusted to $(\mathrm{pH} 7.0)$, autoclaved, mixed and dispensed

9. Hopwood's minimal medium (MM)
Glucose
$10 \mathrm{gm}$
Asparagine
$0.5 \mathrm{gm}$
$\mathrm{K}_{2} \mathrm{HPO}_{4}$
$0.5 \mathrm{gm}$
$\mathrm{FeSO}_{4}-7 \mathrm{H}_{2} \mathrm{O}$
$0.01 \mathrm{gm}$
$\mathrm{KOH}$
$0.3 \mathrm{gm}$
Agar
15 or $20 \mathrm{gm}$
$(\mathrm{pH} 7.0)$

10. Sabouraud's agar (Sab)

Use prepared plates from GIBCO

$\begin{array}{ll}\text { Ncopeptone } & 10 \mathrm{gm} \\ \text { Glucose } & 40 \mathrm{gm} \\ \text { Agar } & 15 \mathrm{gm} \\ \mathrm{H}_{2} \mathrm{O} & 1 \text { liter }\end{array}$

(pH 5.6)

11. Mycobiotic Agar
Soytone
$10 \mathrm{gm}$
Glucose
$10 \mathrm{gm}$
Agar
$15 \mathrm{gm}$
Actidione
$0.5 \mathrm{gm}$
Chloromycetin
$0.05 \mathrm{gm}$
(pH 6.5
Used prepared plates from GIBCO 